\title{
Analysis of the potential use of Distributed Generation in Colombia
}

\section{Análisis del potencial uso de la Generación Distribuida en Colombia}

\author{
Jhan Piero Rojas Suarez ${ }^{1}$ \\ Mawency Vergel Ortega ${ }^{2}$ \\ *Sofia Orjuela Abril ${ }^{3}$ \\ Universidad Francisco de Paula Santander, \\ Cúcuta, Colombia
}

\begin{abstract}
Looking for the availability, access, and distribution of energy resources, the concepts of integration and distributed generation "DG" are created, it seeks to generate economic growth and prosperity, and of course, the reduction of pollutants to the environment. Under this scenario, regulatory laws have been implemented worldwide for the incentive, organization, and inclusion of

$1 \quad$ Facultad de Ingenierías, Universidad Francisco de Paula Santander, Cúcuta, Colombia. Correo jhanpierorojas@ufps.edu.co ORCID iD: https://orcid.org/0000-00032682-9880

2 Departamento de Matemáticas y Estadística, Universidad Francisco de Paula Santander, Norte de Santander, Cúcuta, Colombia, correo: mawencyvergel@ufps.edu.co Orcid: https://orcid.org/0000-0001-8285-2968

3 Facultad de Ciencias Empresariales, Universidad Francisco de Paula Santander, Cúcuta, Colombia. Correo: sofiaorjuela@ufps.edu.co ORCID: https://orcid.org/0000-
\end{abstract} different technologies based on renewable energy. This document contains some of the technologies used for distributed generation and deals with the threats that decrease polluting emissions. In addition, a couple of international cases (Spain and Argentina) are studied from the legal framework and their experience in the introduction of the DG, also seeks to land from these experiences to the Colombian national context located in Law 1517 of 2014, it still has different legal loopholes and is growing. This has allowed the growth of these technologies in our country and allows us to present the different areas with a high potential for electricity generation such as wind and solar energy, for example, in the upper Guajira, in order to present a strategy for implement these DG technologies and contribute to accelerating 
their implementation, giving security to investors and consumers.

\section{KEYWORDS:}

Distributed generation, Energy integration, Electric generation technologies, Legal framework, Renewable Energy.

\section{RESUMEN}

Buscando la disponibilidad, acceso y distribución de los recursos energéticos, se crean los conceptos de integración y generación distribuida "GD", se busca generar crecimiento económico y prosperidad, y por supuesto, la reducción de contaminantes al medio ambiente. Bajo este escenario, se han implementado leyes regulatorias a nivel mundial para el incentivo, organización e inclusión de diferentes tecnologías basadas en energías renovables. Este artìculo analiza tecnologías utilizadas para la generación distribuida y aborda las amenazas que disminuyen las emisiones contaminantes. Además, se estudian un par de casos internacionales (España y Argentina) desde el marco legal y su experiencia en la introducción de la GD, también se busca aterrizar desde estas experiencias al contexto nacional colombiano ubicado en la Ley 1517 de 2014, aún tiene diferentes vacíos legales y está en crecimiento. Esto ha permitido el crecimiento de estas tecnologías en nuestro país y nos permite presentar las diferentes zonas con un alto potencial de generación eléctrica como la energía eólica y solar, por ejemplo, en la alta Guajira, con el fin de presentar una estrategia para implementar estas tecnologías de GD y contribuir a acelerar su implementación, dando seguridad a los inversionistas y consumidores.

\section{PALABRAS CLAVE:}

Generación distribuida, Integración energética, Tecnologías de generación eléctrica, Marco legal, Energías renovables.

\section{INTRODUCTION}

The traditional energy generation, transmission, and distribution facilities in the world face a series of challenges related to sustainability, efficiency, and scalability (IEA ETSAP \& IRENA, 2015). In recent years, both in our country and throughout the world, the conservation of natural resources and protection of the environment has become vitally important, producing a strong impulse in the development of new energy generation technologies at small scales (Segura Heras, 2005), in general, those related to renewable energy sources and even more when it comes to clean energy. Clean energy refers to those forms of obtaining energy that produce zero or minimal impact on the environment during its generation or getting (Energías Limpias: Concepto, Importancia y Ejemplos, n.d.). Among the most popular are wind energy and photovoltaic solar energy, which have a high potential for obtaining in our country (Pasqualino et al., 2015).

Photovoltaic solar energy consists of the transformation of solar energy into electrical energy that can be stored and interconnected to the electrical grid (Rodríguez Murcia, 2008). Meanwhile, the generation of electricity through wind energy consists of the use of wind power, this form of energy is one of the most driven today, in countries such as Germany where it represents $27 \%$ of the total consumption of electrical energy in which an increase of up to $45 \%$ projected to the year 2030 is forecast (Isaac et al., 2008). With the advancement of these energies, a term called energy integration is introduced, which seeks to promote the development of transport, energy, and telecommunications infrastructures, favoring the potential of oil, gas, hydroelectric, and coal reserves (J. Martínez et al., 2013).

With energy integration, countries and their governments motivate and encourage the search for alternative technologies that guarantee sufficient access to energy resources through laws and regulatory policies, ensuring economic 
growth and environmental protection (Freier, 2013). There are various works about energy generation, such as that of Serrano Guerrero, which consists of the computerized simulation of distributed resources based on energy demand, average wind speed, average area radiation, etc. (Serrano, 2012). However, works such as that of García and Palacios analyze the evolution of the integration process of the electricity sector in the Nordic countries that serve as an example of its development for the South American countries (Jairo \& Mario, 2006).

All these energy integration works make it possible to adhere to isolated systems that generate electricity and suggest support for the power of centralized generation networks, This type of generation is called Distributed Generation, which consists of the strategic use of modular electricity generation units installed in isolation or interconnected to the electricity distribution network (Segura Heras, 2005).

The DG seeks to diversify the energy basket, the reduction of fossil fuels, the minimization of the environmental impact (Cadena et al., 2008). In addition, current energy demand forces us to search for new forms of energy generation, among which renewable energy sources are having great success (L. H. Berrío \& Zuluaga, 2014), distributed generation is one of the most accepted strategies to meet the increase in demand for electricity worldwide (Gaitán et al., 2019).

A shared vision of intelligent generation, distribution, and consumption are required that transforms conventional networks into networks with bidirectional flow of power, incorporation of renewable sources, the proximity of generation to consumption centers, high power of autonomy and exchange of energy resource (Mina Casaran et al., 2019), taking into account the regulatory problems associated with the integration of the DG as well as proposing changes in the regulation that allow better integration of it
(Mendez Quezada, 2005), the electro energetic industry is in the maturity phase, and innovation should not be neglected because growth or expansion of capacities and better use of those already installed are required ("La capacidad de absorción para la innovación: Estudio de caso en la Generación Distribuida Cubana," 2012), the reliability of the supply in the DG, reduces the number of interruptions, increases the quality of the service, and allows the efficient use of energy, thus becoming an important alternative within the concept of safe electricity (Javier, 2007).

Benefits such as the reduction of energy losses, improvements in the voltage profile, and decongestion in the distribution lines are some of the many technical advantages that are lost. However, an inappropriate location or dimensioning of the DG in the system can generate adverse effects on the Red (Barker \& De Mello, 2000) (Grisales Noreña et al., 2017). Currently, there are works where methods are developed to solve the above problems, such as location, such as Guerra Sánchez, who devised an algorithm to obtain optimal power and position values for the generator based on the Monte Carlo method (Luis et al., 2012), or as García Castellanos who executed a software for the dimensioning and location of DG in a microgrid (Microrred \& Eduardo García Castellanos Daniela Molina De la Rosa, 2019), with tools and advances such as these, distributed generation and smart grids emerge as a new alternative to electricity service and that in the near future they will modify the architecture of the conventional centralized system, especially distribution grids (Aguayo et al., 2011).

The importance of DG lies in the challenges that countries face in terms of centralized electricity production that is affected every day by gigantic energy demand (Ramos, 2020), and obviously, in reducing damage to the environment (Russi \& Trujillo, 2015), throughout this article, a 
propositional approach to the areas with the greatest energy potential in the Colombian electricity generation market is presented (Kırbıyık, 2004) thus creating better solutions in terms of planning and incursion of new technologies, improvement of the quality of resources and flexibility in the energy system.

\section{METHOD}

The concept of distributed generation (DG) has considerably changed the distribution and transmission of electrical energy over the past few years (Generación distribuida: democratización de la energía eléctrica - Dialnet, n.d.), Although there is no rigorous concept of DG, in general, it can be defined as the generation of electrical energy by means of much smaller installations in relation to conventional plants (Fernández et al., 2010). As the use of cleaner energy becomes more and more imperative, most countries worldwide have chosen to free their electricity markets (Pepermans et al., 2003), encouraging and motivating the production of new generation technologies (Ackermann et al., 2001), with the approval in 2014 of law 1715 in Colombia "through which the integration of non-conventional renewable energy into the national energy system is regulated" (Leyes desde 1992 - Vigencia expresa y control de constitucionalidad [LEY_1715_2014], n.d.) It has created a positive impact and a promising solution to the shortcomings in the provision of energy service in the non-interconnected areas of the country (Jiménez, 2013).

Currently, the Colombian electricity system is based on centralized generation plants, fed by hydric sources and interconnected by transmission and distribution systems, that fail to cover a considerable percentage in the national territory (Miguel et al., 2008), which reaffirms the need and implementation of said technologies and therefore the policies that support, motivate and encourage the generation of clean energy that complements the current electricity distribution system. One way to support energy policies is through studies that allow identifying the consequences (advantages and disadvantages) (Ximena et al., 2013) that are immersed at the time of installation and operation of plants to the interconnected Colombian power system.

Immersed in this scenario, in recent years, there has been a significant increase in the number of DG facilities (David \& Trebolle, n.d.). Still, with them, a series of technical and regulatory problems have also arisen. Within the barriers and challenges that exist to implement DG to interconnected systems are cost, reliability, lack of storage technology, the coordinated development of the energy network at various voltage levels (L. Berrío \& Zuluaga, 2012), (L. H. Berrío \& Zuluaga, n.d.), (J. Rey, P. Vergara, G. Osma, 2013). The objective of this document is to show the potential of DG based on the experiences and results of the schemes and proposed and installed in different countries, taking into account the costs and benefits, in addition to analyzing the various problems that may arise in the field of generation distributed DG.

With the aim of promoting the development and use of unconventional energy sources, mainly those known as renewable, in the Colombian energy system, taking into account its integration into the electricity market, its participation in non-interconnected areas, and other uses as a necessary means for sustainable economic development, the reduction of greenhouse gas emissions and the security of energy supply. The national government creates Law 1715 of 2014, "Through which the integration of non-conventional renewable energies into the National Energy System is regulated.", Which seeks to promote efficient energy management, which includes both energy efficiency and the demand response (Leyes desde 1992 - 
Vigencia expresa y control de constitucionalidad [LEY_1715_2014], n.d.).

Some of the decrees that have been issued in the context of the regulation of law 1715 of 2014 :

- $\quad$ UPME Resolution 703 of December 14, 2018 "By which the procedure and requirements for obtaining the certification that endorses the Non-Conventional Energy Sources (FNCE) projects are established, with a view to obtaining the benefit of the exclusion of VAT and the exemption from the tariff lien dealt with in articles 12 and 13 of Law 1715 of 2014, and other provisions are adopted. "

- $\quad$ MinAmbiente Resolution 1312 of August 11, 2016, "By which the terms of reference for the preparation of the Environmental Impact Study - EIA, required for the processing of the environmental license of projects for the use of continental wind energy sources and other determinations are made. "

- MinAmbiente Resolution 1283 of August 8, 2016, "By which the procedure and requirements for the issuance of the environmental benefit certification for new investments in non-conventional renewable energy sources projects - FNCER and efficient energy management, are established, to obtain the tax benefits referred to in articles 11,12 , 13 and 14 of Law 1715 of 2014 and other determinations are adopted. “

- UPME Resolution 0281 of 2015, "By which the maximum power limit of small-scale self-generation is defined."

- Decree 1623 of 2015, "Whereby Decree 1073 of 2015 is modified and added, with regard to the establishment of the policy guidelines for the expansion of the coverage of electric energy service in the National Interconnected System and in the Non-Interconnected Zones."
With this legal framework that continues growing, the first legal instruments for the use of unconventional energy sources are delivered.

\section{RESULTS AND DISCUSSION}

\subsection{ANALYSIS OF THE INTERNATIONAL CONTEXT - SPAIN AND ARGENTINA.}

In Spain, the DG technologies that have had the most boom have been wind energy, reaching an installed capacity at the end of 2005 of 9300 MW (David \& Trebolle, n.d.). Biomass follows, although its growth has been established in recent years. According to economic incentives, it is predicted that solar energy would have a significant boom. Table 1 shows the installed power from 2000 to 2004, taking into account the following types of technology: cogeneration, Eolic, hydraulic, waste, biomass, waste treatment, and solar.

Table 1: Installed powers of different DG technologies. Source of data: Prepared by the authors based on data from(Sepulveda J., 2012)

\begin{tabular}{|c|c|}
\hline Year & $\begin{array}{c}\text { Total installed power with } \\
\text { renewable energy (MW) }\end{array}$ \\
\hline 2000 & 9213 \\
\hline 2001 & 11190 \\
\hline 2002 & 13317 \\
\hline 2003 & 14933 \\
\hline 2004 & 17154 \\
\hline
\end{tabular}

According to CNE data, at the end of 2003, the production of renewable energy was 17.1997 GWh, which represented $11.27 \%$ of the total production, and where the most important renewable technologies were wind, hydro, biomass, and photovoltaic. In Figure 1, we can see the production of DG with different technologies in 2003. 
Figure 1: DG production in 2003. Source of data: Prepared by the authors based on data from (Sepulveda J., 2012)

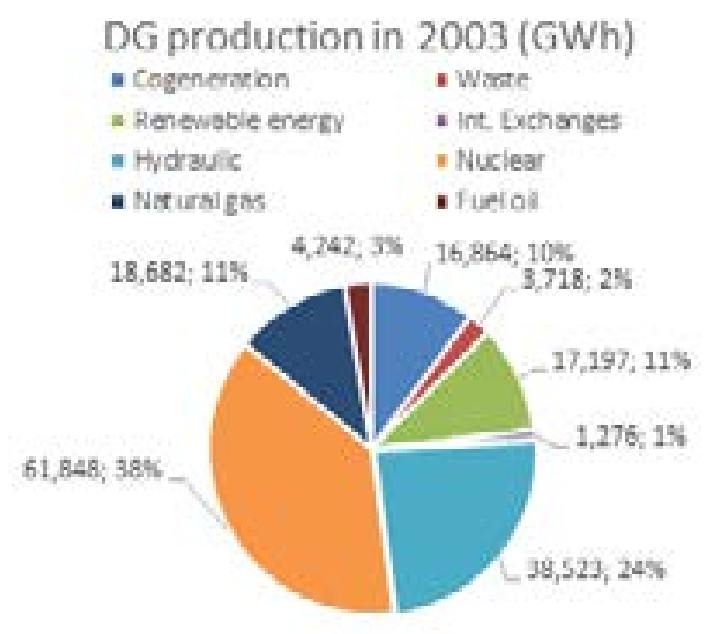

A total of 1,500 million euros were invested per year, and a total of 1,050 million euros was invoiced. This implies that renewable energies provided electricity to $4,776,000$ families, and $16,509,000$ tons of CO2 were avoided, and the import of more than 1 million tons of oil was avoided.

Argentina has an energy matrix highly dependent on fossil fuels, mainly oil and gas, reaching $87 \%$ of the total energy supply. For its part, in the electrical matrix, the participation of fossil fuels has been increasing and reaches $66 \%$ of the total. Natural gas is its main component, and emissions are in the range of an intermediate developing country and well above the average for the region.

In order to take advantage of the existing potential throughout its territory, in addition to large-scale development, it was necessary to incorporate distributed generation integrated into the grid (as renewables are not manageable, they can only be introduced within the energy matrix in a "mix") and have the regulatory feasibility to begin to enhance the possibilities offered by a decentralized generation model.
Within this framework, after a year of debate, the Executive Power of the Argentine Nation promulgated, through Decree 1075/2017, on December 27, 2017, Law No. 27424 of "Regime for the Promotion of Distributed Generation of Renewable Energy Integrated to the Public Electricity Network" (A. N. Martínez \& Porcelli, 2018).

\subsection{FOSSIL FUEL ENGINES, GAS TURBINES, AND MICROTURBINES}

It is the technology usually used for DG. It is a technology with low capital cost, high operating range, fast start-up, high reliability, and high energy conversion efficiency. The power of commonly used generation equipment of this type is less than $1 \mathrm{MW}$. Two types of engines are used, natural gas and diesel engines, the efficiency of these engines is in the $30 \%-50 \%$ range, but the biggest disadvantages of these engines are noise, maintenance costs, and high emissions. These emissions can decrease, with a loss of efficiency changing combustion characteristics using catalytic converters (Segura Heras, 2005).

Gas turbines are generally used in the industry. The fuel is usually natural gas, although LP or diesel can be used. Its capacities are between $265 \mathrm{~kW}$ to $50,000 \mathrm{~kW}$; allow to obtain electrical efficiencies of $30 \%$ and thermal efficiencies of $55 \%$; the combustion gases have a temperature of $600{ }^{\circ} \mathrm{C}$, or have high security of operation; low investment cost; the starting time is short (10 minutes) and with a minimum of physical space. Its maintenance cost is slightly lower for fossil fuel-based engines and also its electrical efficiency (Segura Heras, 2005).

Gas microturbines come from the technological development of the gas turbine for the smallest scale. The technology was originally developed for transportation applications, but now it has found an opportunity in power generation. One of the most notable technical characteristics of 
microturbines is their rotational speed, which is very high. The individual units range from $30-200$ $\mathrm{KW}$ but can be easily combined. Combustion temperatures can ensure very low NOx emission levels. They make much less noise than an engine of comparable size. Natural gas is the most common fuel, in addition to landfill gas, or biogas that can also be used. The main disadvantage of gas microturbines is the high prices compared to gas engines (Segura Heras, 2005).

\subsection{FUEL CELL AND PHOTOVOLTAICS CELLS}

Fuel cells can be defined as solid or compact engines, in replacement of gasoline they use hydrogen and oxygen for electricity generation. The transport sector is the fundamental market for fuel cells. Power generation is seen as a market in which fuel cells are quickly traded. Fuel cells have a great advantage; they have a very high conversion efficiency $(35 \%-60 \%)$, compared to conventional technologies. Its efficiency limits the emissions of gases that cause $\mathrm{CO} 2$ greenhouse effects. With the absence of combustion, other harmful emissions are also low. The fuel cell can operate with very high reliability and thus could also complement the grid electricity supply (David \& Trebolle, n.d.).

Photovoltaics cells consist of converting solar energy into electricity, with an energy efficiency of around $25 \%$. They can be divided into three groups which are:

- Isolated operation: it is used in areas that do not have access to the electrical distribution network and therefore require the use of batteries for storage and a charge regulator.

- Hybrid operation: the photovoltaic panels are connected in parallel to another generation source; it can be a Diesel engine or a wind generator.
- $\quad$ Connected in parallel with the network: the consumption is fed from the panels or from the network, switched by an inverter. This avoids the presence of a battery or a charge regulator, reducing losses and investment.

This technology has the advantage of the cost of fuel since its fuel falls like mana from the sky, but it is considered with high installation costs and allows to feed consumptions far from distribution networks (David \& Trebolle, n.d.).

\subsection{WIND GENERATORS}

The technology that uses wind energy has a power located in ranges from about $3 \mathrm{KW}$ to over 2MW. It is a technology with extensive maturity, with reliability rates close to $97 \%$. In this technology, the mechanical energy of the blades or blades is transformed into electrical energy either by means of an asynchronous generator and a synchronous generator. Asynchronous generators are currently the most widely used, controlled by pulse converters that allow the output voltage to be regulated by modifying consumption. This is a useful option when the equipment is connected to weak networks. In case of a strong injection of power, it could raise the voltage to values above the tolerable ranges.

The main disadvantage of this technology is the difficulty of predicting the power generated due to the unpredictable variations of the wind. Another problem is the flicker phenomenon produced by the passage of the blades in front of the pole where the generator rests, which generates small repetitive variations in voltage (David \& Trebolle, n.d.). The following table shows a summary of the main technologies used in DG distributed generation (Palma-Behnke et al., 2005).

Table 2 presents a summary of the technologies used as DG units, including their capacity and efficiency. 
Table 2: A summary of the technologies used as DG units. Source of data: Prepared by the authors based on data from (Segura Heras, 2005)

\begin{tabular}{|c|c|c|}
\hline Technology & Capacity (kW) & $\begin{array}{c}\text { Efficiency } \\
\text { (\%) }\end{array}$ \\
\hline $\begin{array}{c}\text { Fossil Fuel } \\
\text { Engines }\end{array}$ & $20-10000$ & $36-50$ \\
\hline Gas Turbines & $50-5000$ & $21-40$ \\
\hline Microturbines & $30-200$ & $25-30$ \\
\hline Fuel cell & $50-1000$ & $35-54$ \\
\hline $\begin{array}{c}\text { Photovoltaics } \\
\text { cells }\end{array}$ & $1+$ & - \\
\hline Wind \\
generators
\end{tabular}

Over the years, the technology of wind turbines cost less per unit of installed energy. The cost per unit of wind energy from large-scale systems in places with adequate winds can be even much cheaper than the water energy resource. On the other hand, these systems, whether on any scale, allow access to energy in different places; there are years of drought, but there are no years without wind. As we saw in the summary presented in Table 2, they manage a good balance between efficiency and the capacity they will generate, in addition to being clean energy.

\subsection{HOW TO APPLY DG TO THE COLOMBIAN CONTEXT}

Colombia is a country that enjoys an excellent energy matrix compared to countries with similar latitudes, both in fossil fuels and in renewable resources, but its consumption is based on $78 \%$ of primary resources of fossil origin, the resources available at the national level, such as average solar irradiation of $194 \mathrm{~W} / \mathrm{m}^{2}$ for the national territory, localized winds of average speeds in the order of $9 \mathrm{~m} / \mathrm{s}$ (at $80 \mathrm{~m}$ altitude), particularly in the department of La Guajira, and energy potentials of the order of $450,000 \mathrm{TJ}$ per year in biomass residues, represent attractive potentials compared to those of countries on the planet.

For Colombia, the areas that have been identified as potential areas that the country can develop if it is proposed are the following:

- $\quad$ The development of wind projects in high potential areas, starting with the department of La Guajira.

- The massive development of distributed solar self-generation PV systems on a small and medium scale.

- The development of cogeneration projects is based on the use of biomass for energy purposes.

- $\quad$ The development of geothermal projects in high potential areas such as the Ruiz volcanic massif area.

These zones were defined based on different criteria such as the resource's potential and the cost reduction achieved thanks to technological developments in recent years and decades, the interest of local actors in developing projects, and the opportunity to bring sustainable solutions. Cheaper than diesel to areas that are of special interest to the National Government to extend the coverage of electric power service provider.

The proposed strategy to procure the integration of the DGs into the Colombian national energy system is considered to be based on the legal framework established by Laws 142 and 143 of 1994 (Law of domiciliary public services and law of electrical energy), Law 1665 of 2013 (approval of the statute of the International Renewable Energy Agency -IRENA-) and Law 1715 of 2014. The strategy aims to positively influence the actions and decisions that will be carried out by the government from now on, through two main branches that mainly cover the integration 
of distributed generation and cogeneration projects for the delivery of electrical energy from the identified opportunity areas (Valencia, 2015). Figure 2 shows the unexploited energy capacity of the different areas of the country exposed above.

From Figure 2, we see the great energy capacity that we would have when installing wind generators in the study area. The difficulty of this type of project is to properly organize the prior consultation and negotiation processes with the communities in such a way as to generate security for the investor in the communities with legitimate rights on the areas of influence and the dimensioning of the costs to be incurred in these processes of involvement, concessions, benefits, and negotiation with said communities

Figure 2: Accumulated capacity in different country zones. Source of data: Prepared by the authors based on data from (Valencia, 2015)

\section{Accumulated Capacity (MW)}

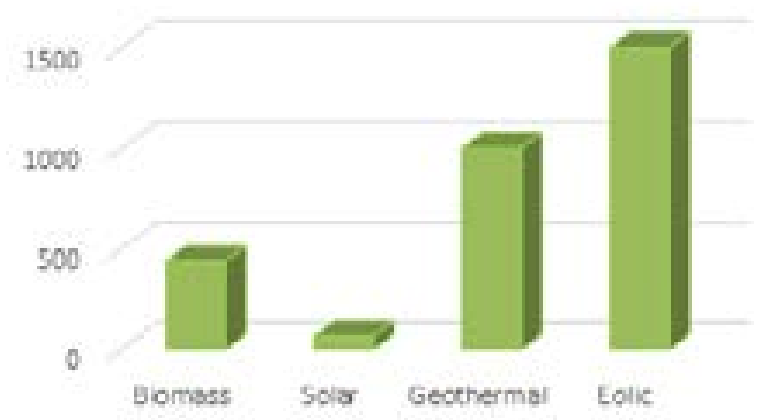

The absence of a technical and operational regulation that guides and assures the development agents about the specific requirements to be met from the very design of their projects in order to be interconnected to the SIN (National Interconnected System) represents a barrier that could be overcome through the adoption or production of specific regulations in this regard. Meanwhile, the absence of transmission networks near the areas with the greatest potential of the wind resource (Alta Guajira) to interconnect these projects to the SIN in an economically viable way for the investor represents an important barrier to the development of this generation opportunity. Electrical. In the case of the installation of small-scale self-generation PV solar systems, the main identified drawbacks (prior to the issuance of Law 1715) represent an inability to deliver surplus energy to the grid by these systems, the absence of defined energy policy in relation to the use of this source, and the absence of specific technical requirements for the connection of these systems.

For the problem of delivering surpluses to the grid, Law 1715 of 2014 introduced the possibility of carrying it out, with the incentive of accessing a credit scheme that will govern for smallscale auto generators with non-conventional energy sources, which should be regulated by the regulatory authority. Law 1715 of 2014 also covers the identified absence of an energy policy that will cover the promotion and development of generation from the solar resource, among other unconventional energy sources.

As fundamental recommendations to achieve the integration of non-conventional renewable energy sources into the national energy system through the development of identified opportunities, the following are proposed: Regulate the incentives provided by Law 1715 through joint interinstitutional work in which entities such as UPME, ANLA, and DIAN participate; Issue simple, agile, clear and properly controlled procedures that are affordable for both small and large investors, and that are widely disseminated for effective use. It is also proposed to keep records that can be managed with transparency, making them visible to the public to demonstrate the effects obtained from the application of the Law, and likewise to make explicit the applicability of incentives to both electrical and thermal generation projects with sources of renewable energy (Valencia, 2015). 


\section{CONCLUSIONS}

The benefits of the DG installed near the generation plants are very important. However, the barriers caused by the presence of said generation in the interconnected networks may not be as positive if the regulation and norms do not adapt and define new rules that help solve the technical problems that arise. The DG's contribution to the Colombian case is made through the application in a legal environment through the contribution of Law 1715 of 2014, reflected in Article 8 on the promotion of small and large-scale self-generation and distributed generation. In terms of regulation, there is no regulatory framework that contemplates the incorporation of the DG in the interconnected national system. Therefore, some results cannot be fully clarified, nor can the usefulness of the inclusion of DG be evidenced. Apart from the regulatory framework, research is required on distributed generation technology and its level of penetration.

The definition, role, and contribution of Distributed Generation vary from country to country, since it depends on energy policies and the regulations adopted to encourage its introduction, especially when this activity is associated with the use of renewable energy resources and It allows obtaining electrical energy at a reasonable price for the user, reducing the environmental impact (energy security). In relation to the experience of the legislation of other countries, it is recommended that the introduction of Distributed Generation be carried out with a gradual and programmed penetration, previously considering the study of selected areas in the networks of electricity distribution companies to determine the level of penetration that they can support, being recommended its implementation through pilot programs.
The Colombian electricity system has historically been characterized by strong variations in the field of development, which have compromised its stability and capacity. Currently, the national electricity system is based on centralized generation plants, fed by water sources and interconnected by transmission and distribution systems, which fail to cover a considerable percentage of the national territory. Although with many details, the progress of the national electrical system and the inclusion of the DG has managed to find an important space for participation after important periods of consolidation of centralized electrical systems. Likewise, potential electricity generation opportunities were raised in different areas of the country.

In order to especially support the development of renewable energy projects, and specifically that of DG projects with these sources, and taking into account the provisions of Law 1715 of 2014 , it is proposed to issue simple, agile, clear, and proper controls, which are affordable for both small and large investors, and which are widely disseminated for effective use. It is proposed to keep records that can be managed with transparency, making them visible to the public to demonstrate the effects obtained from the application of the Law, and likewise to make explicit the applicability of incentives to both electrical and thermal generation projects with energy sources renewable. 


\section{BIBLIOGRAPHIC REFERENCES}

Ackermann, T., Andersson, G., \& Söder, L. (2001). Distributed generation: A definition. Electric Power Systems Research, 57(3), 195-204. https://doi.org/10.1016/S03787796(01)00101-8

Aguayo, F., Martinez, A., \& Juan, L. (2011). Nuevo paradigma en sistemas electricos: GENERACIÓN DEISTRIBUIDA Y REDES INTELIGENTES. In Idus.Us.Es. https:// idus.us.es/xmlui/handle/11441/48905

Barker, P. P., \& De Mello, R. W. (2000). Determining the impact of distributed generation on power systems: Part 1 Radial distribution systems. Proceedings of the IEEE Power Engineering Society Transmission and Distribution Conference, 3, 1645-1656. https://doi.org/10.1109/ pess. 2000.868775

Berrío, L. H., \& Zuluaga, C. (n.d.). 4957-298931-Pb. 3461.

Berrío, L. H., \& Zuluaga, C. (2014). Smart Grid and solar photovoltaic energy as renewable energy source for the distributed generation in the global energy context. Ingeniería Y Desarrollo, 32(2), 369-396. https://doi. org/10.14482/inde.32.2.4957

Berrío, L., \& Zuluaga, C. (2012). Concepts, standards and communication technologies in smart grid. 2012 IEEE 4th Colombian Workshop on Circuits and Systems, CWCAS 2012 - Conference Proceedings. https://doi.org/10.1109/ CWCAS.2012.6404056

Cadena, A. I., Botero, S., Táuta, C., Betancur, L., \& Vesga, D. (2008). \&quot; Regulación para incentivar las energías alternas y la generación distribuida en Colombia \&quot; (Conclusiones) \&quot; Regulation to foster renewable energy and distributed generation in Colombia \&quot; - Summary Ángela Inés Cadena. Redalyc, 121-4993. https://doi.org/0121-4993

David, A. :, \& Trebolle, T. (n.d.). LA GENERACIÓN DISTRIBUIDA EN ESPAÑA.

Energías Limpias: Concepto, Importancia y Ejemplos. (n.d.). Retrieved April 3, 2020, from https://concepto.de/energias-limpias/

Fernández, M. C., Fernández, M. C., Fernández, M. F., Fuentes, R. D., \& Montiel, Á. C. (2010). Electric Power Quality and Distributed Generation in Cuba Calidad de la energía y generación distribuida en Cuba. Revista Cubana de Ingeniería, 1(3), 41-50. https://doi.org/10.1234/rci.v1i3.28

Freier, A. (2013). Aproximación a la importancia de la integración energética en Mercosur. Studia Politicæ, 0(28), 37-46.

Gaitán, L. F., Gómez, J. D., \& Rivas-Trujillo, E. (2019). Quasi-Dynamic Analysis of a 438 Local Distribution System with Distributed Generation. Study Case: The IEEE 13 Node System. TecnoLógicas, 22(46), 195-212. https://doi.org/10.22430/22565337.1489

Generación distribuida: democratización de la energía eléctrica - Dialnet. (n.d.). Retrieved April 2, 2020, from https://dialnet.unirioja. es/servlet/articulo?codigo $=4547088$

Grisales Noreña, L. F., Restrepo Cuestas, B. J., \& Jaramillo Ramirez, F. E. (2017). Ubicación y dimensionamiento de generación distribuida: Una revisión. Ciencia e Ingeniería Neogranadina, 27(2), 157-176. https://doi.org/10.18359/rcin.2344

IEAETSAP, \& IRENA. (2015). Renewable Energy Integration in Power Grids. Technology Brief. April, 1-36. 
Isaac, I. A., Biechl, H., \& Gonzalez, J. W. (2008). La energía eólica en Alemania: experiencias a tener en cuenta para el caso colombiano. Revista Investigaciones Aplicadas, 2(2), 52-64.

J. Rey, P. Vergara, G. Osma, and G. O. (2013). Analysis of the Inclusion of Smart Grids Technology in the Colombian Electric Power System.

Jairo, J., \& Mario, C. (2006). La integración energética de los países nórdicos -Nord Pool- lecciones para otros mercados. Lecturas de Economia, unknown(64), 119142.

Javier, A. (2007). Planeación y Optimización Económica de Sistemas de Gneración Distribuida en Usaquén. 117.

Jiménez, K. F. (2013). Políticas públicas en Colombia de Generación distribuida en nuevas Fuentes energéticas: El Caso de la Geotermia y las Zonas no interconectadas. Via Inveniendi Et ludicandi, 8(2), 150 182. https://doi.org/10.15332/s19090528.2013.0002.07

Kırbıyık, S. (2004). No

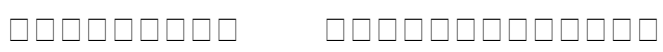

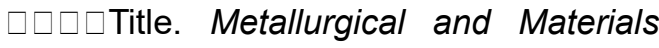
Transactions A, 30(8), 2221.

La capacidad de absorción para la innovación: estudio de caso en la Generación Distribuida Cubana; The absorptive capacity for innovation: study case on Cuban's distributed generation system. (2012). Revista Científica de Ingeniería Energética, 33(3), 217-228.

Leyes desde 1992 - Vigencia expresa y control de constitucionalidad [LEY_1715_2014]. (n.d.). Retrieved April 2, 2020, from http:// www.secretariasenado.gov.co/senado/ basedoc/ley_1715_2014.html
Luis, A. :, Guerra Sánchez, G., Antonio, J., \& Velasco, M. (2012). Localización óptima de generación distribuida en sistemas de distribución trifásicos con carga variable en el tiempo utilizando el método de Monte Carlo.

Martínez, A. N., \& Porcelli, A. M. (2018). Análisis del marco legislativo argentino sobre el régimen de fomento a la generación distribuida de energía renovable integrada a la red pública. Lex Social: Revista de Derechos Sociales, 8(2), 179-198.

Martínez, J., Domínguez, O., \& Finetti, J. E. (2013). VIII CAIQ2015 y 3 JASP. EAFIT, Journal of International Law, 4, 30-46. http://www.aaiq.org.ar/SCongresos/ docs/06_029/papers/09a/09a_1640_383. pdf

Mendez Quezada, V. H. (2005). Generación distribuida: aspectos técnicos y su tratamiento regulatorio. 1.

Microrred, U., \& Eduardo García Castellanos Daniela Molina De la Rosa, J. (2019). HERRAMIENTA SOFTWARE PARA DIMENSIONAMIENTO Y LOCALIZACIÓN DE GENERACIÓN DISTRIBUIDA EN. Barranquilla, Universidad del Norte, 2019.

Miguel, J., González, M., Alberto, C., Daza, D., Humberto, C., \& Urueña, G. (2008). Análisis del esquema de generación distribuida como una opción para el sistema eléctrico colombiano Distributed generation scheme analysis as an option for colombian electrical system. In Rev. Fac. Ing. Univ. Antioquia N. ${ }^{\circ}$ (Vol. 44).

Mina Casaran, J. D., Echeverry, D. F., \& Lozano Moncada, C. A. (2019). Una propuesta metodológica para la concepción técnica de micro-redes. Revista Ingenierías Universidad de Medellín, 18(34), 199-218. https://doi.org/10.22395/rium.v18n34a12 
Palma-Behnke, R., Cerda, J. L. A., Vargas, L. S., \& Jofré, A. (2005). A distribution company energy acquisition market model with integration of distributed generation and load curtailment options. IEEE Transactions on Power Systems, 20(4), 1718-1727. https://doi.org/10.1109/ TPWRS.2005.857284

Pasqualino, J., Cabrera, C., \& Chamorro, M. V. (2015). articulo_8 Impacto ambiental de las FNCE. 68-75.

Pepermans, G., Driesen, J., Haeseldonckx, D., D'haeseleer, W., Belmans, R., \& Driesen, J. (2003). DISTRIBUTED GENERATION: DEFINITION, BENEFITS AND ISSUES. In Elsevier. https://www.sciencedirect.com/ science/article/pii/S0301421503003069

Ramos, E. (2020). La generación distribuida: El camino hacia la producción descentralizada de electricidad y pautas para su reglamentación. Forseti: Revista de Derecho, 8(11), 7-35. https://doi. org/10.21678/forseti.v8i11.1255

Rodríguez Murcia, H. (2008). Energias Colombia. Revista de Ingenieria Universidad de Los Andes, 83-89.

Russi, G. L., \& Trujillo, E. R. (2015). Evaluación del Impacto de la Generación Distribuida mediante Índices Normalizados con base en la Normatividad Colombiana y Estándares IEEEImpact Assessment of Distributed Generation using Standardized Indexes based on Colombian Regulations. Ingeniería, 20(2), 1-1. https://doi. org/10.14483/23448393.8651

Segura Heras, I. (2005). UNIVERSIDAD POLITÉCNICA DE VALENCIA EVALUACIÓN DEL IMPACTO DE LA GENERACIÓN DISTRIBUIDA EN SISTEMASDEDISTRIBUCIÓNPRIMARIA DE ENERGÍA ELÉCTRICA.
Sepulveda J., G. C. (2012). La generación distribuida en España. ... Universidad Comillas de Madrid. Madrid, España, 99. https://iit.upcomillas.es/docs/TM-06-004. pdf

Serrano, X. (2012). Desarrollo de un modelo de simulación para la integración energética de recursos distribuidos mediante trnsys.

Valencia, J. (2015). Integración de las energías renovables no convencionales en Colombia. Ministerio de Minas y Energía, 370. https://doi.org/10.1021/ja304618v

Ximena, S., Quintero, C., David, J., \& Jiménez, M. (2013). The impact of distributed generation on the colombian electrical power system: a dynamic-system approach. Tecnura, 17(35), 77-89. 